\title{
Screening for susceptibility and tolerance to Meloidogyne incognita and M. javanica in okra cultivars in Iraq
}

\author{
Basil H. Kandouh"1, Alaa E. Hasan ${ }^{1}$, Asmaa M. Abd-Al-Rasoul ${ }^{2}$ and Brent S. Sipes ${ }^{3}$ \\ (1) Department of Plant Protection, Faculty of Agriculture, University of Kufa, Iraq, Email: basilh.noamani@uokufa.edu.iq; \\ (2) Department of Plant Protection, College of Agriculture and Forestry, University of Mosul, Iraq; \\ (3) Department of Plant Entomology and Plant Pathology, \\ College of Tropical Agriculture and Human Resources, University of Hawaii, Manoa, USA
}

\begin{abstract}
Kandouh, B.H., A.E. Hasan, A.M. Abd-Al-Rasoul and B.S. Sipes. 2019. Screening for susceptibility and tolerance to Meloidogyne incognita and M. javanica in okra cultivars in Iraq. Arab Journal of Plant Protection, 37(3): 279-285.

Ten okra cultivars were screened for their susceptibility and resistance/tolerance to the root-knot nematodes Meloidogyne incognita and $M$. javanicain in a two-trial experiment under ambient conditions. 14 days old okra seedlings were inoculated with 3000 egg/J2 of $M$. incognita or $M$. javanica. The nematode reproduction factor (Rf) was used to determine susceptibility or resistance among tested cultivars, and cultivars were considered highly susceptibleif $\mathrm{Rf} \geq 2$, susceptible if $2>R f \geq 1$ and resistant if $\mathrm{Rf}<1$. Whereas, magnitude of reduction in plant shoot weight $(\mathrm{ShW})$ over the control indicated tolerance and the categories tolerant, moderately tolerant and intolerant were established, when ShW reduction was $<10 \%, 10-20 \%$ and $>20 \%$, respectively. Most of the cultivars tested were susceptible at various levels. Although Rf of $M$. javanica was always higher than that of $M$. incognita, but the plant growth (Shoot weight) was rather more highly affected by $M$. incognita than by $M$. javanica. Lahluba was the only resistant cv. to both nematode species, tolerant to $M$. javanica but intolerant to $M$. incognita ( $>30 \%$ ShW reduction). Taiwan Hybrid F1 was resistant/intolerant (shoot and root weight were decreased) to $M$. javanica and susceptible/moderately tolerant to M. incognita. Although M. incognita infected Musoliya, it showed high rates of egg masses (EMR) and galling (GR), thus it was moderately resistant and highly tolerant. Betraa was the most susceptible to both nematode species with moderate tolerance to $M$. javanica and intolerant to $M$. incognita. Clemson Spineless was susceptible/tolerant to $M$. incognita despite of EMR, GR and Rf high values. All the other cultivars failed in the category of susceptible/intolerant. The galling index did not always reflect the reproduction index or the rate of shoot weight reduction. Nematode reproduction $\mathrm{Rf}$ was reliable as susceptibility-resistance indicator as well as the extent of ShW reduction for tolerance assessment. The severe root weight reduction due to nematode infection may also indicate plant intolerance. Different levels of resistance and tolerance to nematode infection can be found among okra varieties. Selecting okra cultivars resistant and tolerant to Meloidogyne spp. is an effective approach to maintain high yield, mitigate yield costs and manage the nematode population.

Keywords: Okra, RKN, resistance, $M$. javanica, $M$. incognita, tolerance.
\end{abstract}

\section{Introduction}

Okra (Abelmoschus esculentus L. Moench) is an important summer vegetable crop grown almost in all parts of Iraq. The acreage cultivated with okra is usually comparable to that of watermelon and cucumber, and comprises $14 \%$ of total area cultivated with major vegetable crops (CSOI, 2016). Although Iraq is among the first ten biggest okra producing countries in terms of total production, its productivity (ton/hectare) does not exceed $50 \%$ of that produced in India and Egypt or $75 \%$ of Jordan and Pakistan (FAO, 2016). Root-knot nematode (RKN) in Iraq, as in most world countries, is the most prevalent nematode associated with vegetable crops causing serious yield loss (Stephan, 1988; Stephan et al., 1998; Taylor and Sasser, 1982,). Meloidogyne-infected okra plants show poor growth, stunting, premature wilting and leaf chlorosis and the root system exhibits round to elongated galls of different sizes mostly coalesced and appear on both main and secondary roots, leading to plant death or yield reduction (Sikora and Fernandez, 2005).

http://dx.doi.org/10.22268/AJPP-037.3.279285

(C) 2019 Arab Society for Plant Protection الجمعية العربية لوقاية النبات
Although the importance of okra in Iraq and middleeast, studies on nematode problems associated with its cultivation are few, even in the case of the most problematic RKN. Meloidogyne spp. were found to be very damaging to okra in Egypt (Ibrahim et al., 1982) and north of Iraq (Al-Sabie and Ami, 1990). Most of okra varietal screening for resistance to RKN studies were done in India, Nigeria and Pakistan, where okra is widely cultivated (Darekar and Ranade, 1990; Hussain et al., 2014; Jain and Gupta, 1996; Kedarnath et al., 2017; Mahajan and Sharma, 1979; Martinello et al., 2001; Mohanta and Mohanty, 2012; Mukhtar et al., 2014; Ramakrishnan et al., 1993; Rekha and Gowda, 2000; Sharma and Trivedi, 1990; Sheela et al., 2006; Singh et al., 1993; Thies and Fery 1994). Most of these studies evaluated susceptibility of okra to the common $M$. incognita which is the most dominant in tropical and subtropical humid climate. M. javanica was tested on some Indian okra varieties by Jain and Gupta (1996). Thirty six okra accessions and landraces were screened against $M$. javanica in Jordan, some of them showed moderate resistance, whereas the rest were susceptible at different levels (Karajeh and Salameh, 2015). Information on okra varietal screening to both RKN species is limited and scarce (Martinello et al., 2001). Both M. incognita and M. javanica were found in mid and south of Iraq on vegetable 
crops with predominance of $M$. javanica (60-70\%) over $M$. incognita populations (30-40\%) (Alwaily et al., 2011; Kandouh, 2018; Taylor and Sasser, 1982).

Recently, several imported and local okra cultivars are available to farmers in the Iraqi markets. Their responses in terms of susceptibility and tolerance to $M$. incognita or $M$. javanica are not determined in Iraq. Absence of fumigant nematicides makes the control of nematodes much more difficult and challenging (Haydock et al., 2006). Appropriate post planting non-fumigants, if available, are not only costly and toxic with long waiting period but also requiring well trained farmers for their application. Practically, resistant cultivars provide the best economical and environment friendly nematode control approach. Screening for resistance and tolerance may be slow, but finding a stable resistant plant cultivar is worth the time spent and effort (Brown et al., 1996; McDonald and Linde, 2002). The objective of this study, therefore, was to investigate susceptibility and tolerance of okra cultivars in Iraq to the root-knot nematodes $M$. incognita and $M$. javanica.

\section{Materials and Methods}

\section{Inoculum}

Root-knot nematodes were collected from infested okra fields. Species identity was confirmed according to Eisenback (1985) using the perennial pattern technique (Taylor and Netscher, 1974) and pure cultures were established from single egg masses. Egg masses of $M$. incognita or $M$. javanica were inoculated to tomato plants Solanum lycopersicum cultivar Mermande or okra $A$. esculentus cultivar Hussainawiya (a local cultivar) and plants were maintained in the green house. 90 days later, plants were uprooted, washed and Meloidogyne eggs and second stage juvenile $\mathrm{J} 2$ were extracted and collected using the $\mathrm{NaOCl}$ method (Hussey and Barker, 1973).

\section{Seed sources of okra cultivars}

Okra seeds of 10 cultivars were collected from different market places of Najaf and some other parts of Iraq. Seeds of cultivars 'Clemson spineless 1' (USA), 'Clemson spineless 2 (Turkey)' and 'Taiwan Hybrid F1' (Taiwan) are sold in the Iraqi market in sealed packs treated with pesticide. Cultivar 'Musoliya' seeds were obtained from Musol province through the Faculty of Agriculture, University of Musol. 'Hilawiya' and 'Btera' seeds were from Al-Hilla local market. The other four cultivars 'Husainawiya', 'Lahluba', 'Betraa' and 'Egypt Red' were locally purchased from an agriculture dealer in Najaf.

\section{Experimental design}

Two liter pots were filled with steam sterilized soil mix [regular field soil, river sand and coarse sand at 2:1:1 ratio (v/v)]. Pots were planted with 3 to 5 okra seeds each. Two weeks after planting, the emerged plants were thinned to one seedling per pot and inoculated with initial population (Pi) of $M$. incognita or $M$. javanica at population density of 3000 eggs/pot diluted in $10 \mathrm{ml}$ aliquots. Pots were placed on benches and maintained in a cage under ambient temperature of $30-42{ }^{\circ} \mathrm{C}$. Pre-plant pots were incorporated with fertilizer (DAP) at the rate of $5 \mathrm{~g}$ per pot, followed later by two additional applications during the growing period. Irrigation was applied as needed. The ten chosen okra cultivars were screened for their resistance and tolerance to the RKN $M$. incognita and $M$. javanica. This experiment was repeated in two trials, April 1-June 15, 2017 for the $1^{\text {st }}$ trial and May 1 - July 15, 2017 for the $2^{\text {nd }}$ trial. Experimental units were arranged in a complete randomized design (CRD) with eight replicates.

\section{Data collection}

Sixty days after inoculation, all plants of the ten okra cultivars were uprooted and each root system was carefully washed to remove soil. To determine number of $\mathrm{J} 2$ from plant soil, a $100 \mathrm{ml}$ from each plant pot was taken and subjected to floatation and centrifugation extraction (Barker, 1985). Plant's vegetative growth parameters (weight and length of shoot and root) were recorded for tolerance comparison among cultivars across nematode species. Roots were stained (Thies et al., 2002) and numbers of galls and egg masses on the entire root system were counted. The roots were then subjected to $\mathrm{NaOCl}$ egg extraction (Hussey and Barker, 1973). Resistance was assessed based on Galling index (GI), egg mass index (EMI) and reproduction factor (Rf), where $\mathrm{Rf}=\mathrm{Pf}$ (final population)/Pi (initial population). The galling and egg masses indices were rated using a scale of 0 to 5 , where: $0=$ no galls/egg masses; $1=1-2$ galls/egg masses; $2=3-10$ galls/egg masses; $3=11-30$ galls/egg masses; $4=31-100$ galls/egg masses; 5= more than 100 galls/egg masses (3). Rf values were used to determine cultivars susceptibility or resistance. Cultivars with $\mathrm{Rf} \geq 2$ were considered highly susceptible, those with $2>\mathrm{Rf} \geq 1$ were considered susceptible, whereas cultivars with $\mathrm{Rf}<1$ were considered resistant.

\section{Statistical Analysis}

Data obtained from the two trials were subjected to analysis of variance (ANOVA) and means were compared (Noe, 1985). The Waller-Duncan's multiple range test was used for means separation, wherever appropriate $(P \leq 0.05)$. Data analysis was carried out using SAS (SAS, Inc., Cary, NC).

\section{Results}

\section{Screening for resistance and tolerance}

Data from trial 1 were consistent with those collected from trial 2, and they were combined for analysis. The okra cultivars showed various reactions to different Meloidogyne species. Shoot weight (ShW) and shoot length (ShL) was reduced in a similar manner due to nematode infection (Figure 1). In case of $M$. incognita infection, all the cultivars, except Clemson Spineless and Musoliya, were intolerant and showed $\mathrm{ShW}$ reduction range from $11 \%$ to $34 \%$, while ShL of all the cultivars showed higher reduction ranged from 13 to $41 \%$ over the control plants. ShW and ShL were generally less affected by $M$. javanica infection. Btera and Lahluba were the only tolerant cultivars with $\mathrm{ShW}$ and $\mathrm{ShL}$ reduction $\leq 10 \%$. Clemson Spineless and 
Clemson Turkey had the highest ShW reduction (24-34\%), whereas most cultivars showed moderate ShW reduction that ranged from 10 to $17 \%$. Similar responses were observed in case of ShL. ShL of Clemson Spineless was the most reduced (31\%), whereas ShL of Lahluba was the least affected (2\%). Regarding root weight (RW), RKN infection almost always resulted in a RW higher than that of noninfected plants. Generally, RW increased as the gall rating index (GRI) increased (Table1). Plants infected with $M$. incognita had much higher RW compared to those infected with $M$. javanica of the same cultivar. However, RW was reduced over the control only in Lahluba and Tiawan Hybrid cvs. due to $M$. javanica infection (Figure 1). $M$. javanica reduced RL by $42 \%$ in cv. Clemson Spineless and $31 \%$ in Clemson Turkey, whereas Lahluba was less affected with $5 \% \mathrm{RL}$ reduction, as compared to the controls. $M$. incognita infected plants of all cultivars showed RL reduction that ranged from 2 to $27 \%$ over their control plants. Mosuliya, Clemson Spineless and Hillawiya showed low RL reduction $(2-7 \%)$ due to $M$. incognita infection, whereas all other cultivars showed higher RL reduction $(\geq 10 \%)$.
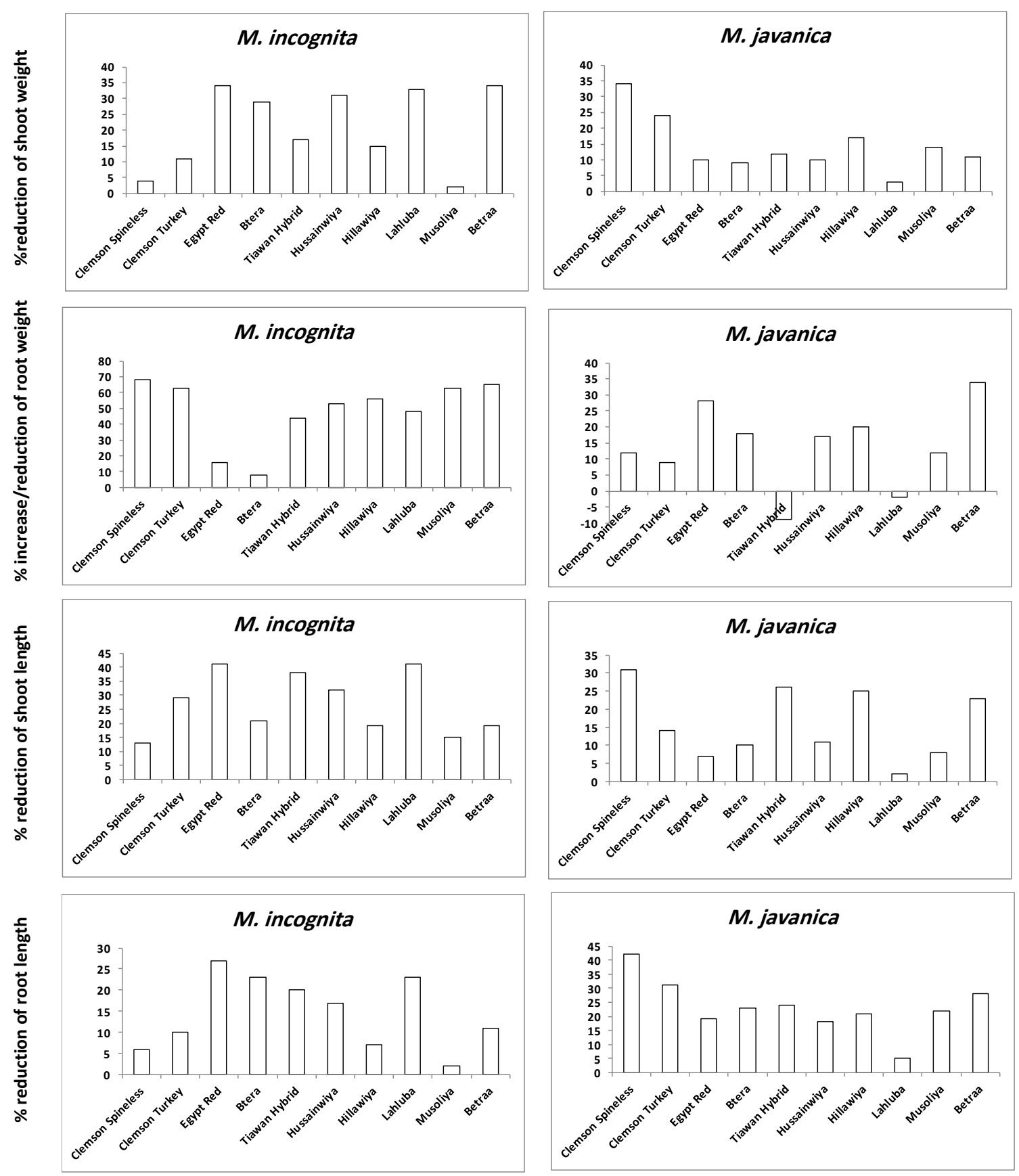

Figure 1. Effect of Meloidogyne incognita and M. javanica infection on shoot and root weight and length of different okra cultivars. Values are means of eight replicates. 
The two RKN species behaved differently on different okra cultivars. Egg mass rating (EMR) values were generally higher in the $M$. javanica with a range from 2.62 to 3.5, whereas $M$. incognita infected plants had EMR that ranged from 2.25 to 3 . However, within cultivar, Meoidogyne species did not produce high differences in EMR. The highest EMR was recorded on Clemson Spineless infected with $M$. javanica (3.5), whereas the lowest EMR was on Lahluba (2.25-2.62), regardless of the RKN species. Taiwan Hybrid showed moderate EMR for both nematode species compared to all other cultivars. Root galls rating index (GR) on the other hand was generally higher in all $M$. incognita infected cultivars ranging from 3.75 to 4.25 , but GI in case of $M$. javanica infected plants ranged from 2.12 in Taiwan Hybrid to 3.87 in Clemson Turkey. GI values did not perfectly reflect the reproduction factor (Rf) values in some of the tested cultivars. In this study, Rf was used to determine susceptibility or resistance among cultivars.

Regardless of the RKN species, most of the cultivars were found to be susceptible or highly susceptible with $\mathrm{Rf}$ higher than one $(R f \geq 1)$. Unlike GI which was higher in all the cultivars infected with $M$. incognita, Rf of all cultivars, except for Taiwan Hybrid, was higher in case of infection with $M$. javanica. Cultivar Betraa was the most susceptible to both nematode species, while Lahluba was resistant to both species.

Taiwan Hybrid was resistant to $M$. javanica $(\mathrm{Rf}<1)$, but at the same time was among the most susceptible ones to $M$. incognita. Cultivar Mosuliya was resistant $(\mathrm{Rf}<1)$ to $M$. incognita, but it was susceptible to $M$. javanica infection. All the other cultivars, regardless of the nematode species, were either susceptible or highly susceptible to infection.

\section{Discussion}

Gall rating index (GR) can be a reliable measure in varietal screening to evaluate plant resistance or susceptibility (Mukhtar et al., 2014), especially if it perfectly reflects the nematodes reproduction rate (Cook and Evans, 1987; Roberts, 2002). The GR index in our study reflected plant response to infection, but it was not a perfect indicator for plant resistance or susceptibility. The cultivar Lahluba, based on the GR only, could be identified as moderately resistant to $M$. javanica and susceptible to $M$. incognita. However, this does not support our findings as Lahluba (based on $\mathrm{Rf}$ index) was the only resistant cultivar to both nematode species with relatively same $\mathrm{Rf}$ values $(\mathrm{Rf}<1)$. Another approach was used previously (Sasser et al., 1984; Canto-Saenz, 1985) based on GR and Rf to identify resistant, tolerant, hyper susceptible and susceptible genotypes. Based on this approach, plant genotypes with $\mathrm{Rf}$ $\geq 1$ and GR $\leq 2$ are considered tolerant. However, some plant species or cultivars within a species may support high nematode reproduction $\mathrm{Rf}>1$ with few or no galls. Taiwan Hybrid in this study was among most susceptible/intolerant cultivars to $M$. incognita with $\mathrm{Rf} \geq 1$ and ShW reduction $>$ $10 \%$, but it was resistant $(\mathrm{Rf}<1)$ to $M$. javanica infection with reduction in ShW and RW. Mosuliya also was not a good fit to this approach, as it was resistant/tolerant to $M$. incognita with $\mathrm{Rf}<1$ and $\mathrm{ShW}$ that did not differ from the control. The GR approach could not determine susceptibility or resistance in some evaluated cultivars and could not reflect tolerance level. It is already known that nematode reproduction and root galling are two different independent phenomena in the plant-nematode interaction (Williamson and Roberts, 2009). Generally, resistant tomato plants that possess $M i-1$ gene or cowpea plants with $R k$ gene suppress nematode reproduction and reduce root galling (Das et al., 2008). However, other types of plant resistance were also observed where root galling was greatly suppressed but the nematode reproduction was not affected and vice versa. Genes that are involved in suppression of root galling but do not suppress nematode reproduction were identified earlier (Garcia et al., 1996; Roberts et al., 2008). This study confirmed that the reproduction factor is the most reliable criteria to determine plant susceptibility or resistance, whereas plant growth and yield parameters are good indicators for plant tolerance.

Table 1. Egg mass rating (EMR), gall rating (GR) and reproduction factor (Rf) of Meloidogyne incognita and M. javanica on ten different okra cultivars

\begin{tabular}{lcccccccc}
\hline \multirow{2}{*}{ Okra cultivars } & \multicolumn{2}{c}{ Egg mass rating (EMR) } & & \multicolumn{2}{c}{ Gall rating (GR) } & & \multicolumn{2}{c}{ Reproduction factor (Rf) } \\
\cline { 2 - 3 } M. incognita & M. javanica & & M. incognita & M. javanica & & M. incognita & M. javanica \\
\hline Clemson spineless & $3.0 \mathrm{a}$ & $3.3 \mathrm{a}$ & & $3.7 \mathrm{~b}$ & $3.8 \mathrm{a}$ & & $1.1 \mathrm{ab}$ & $3.0 \mathrm{ab}$ \\
Clemson Turkey & $2.8 \mathrm{a}$ & $2.8 \mathrm{abc}$ & & $4.2 \mathrm{a}$ & $4.0 \mathrm{a}$ & & $1.3 \mathrm{ab}$ & $2.3 \mathrm{bcd}$ \\
Egyptian Red & $2.8 \mathrm{a}$ & $2.8 \mathrm{abc}$ & & $4.0 \mathrm{ab}$ & $4.0 \mathrm{a}$ & & $1.5 \mathrm{a}$ & $2.5 \mathrm{abc}$ \\
Btera & $3.0 \mathrm{a}$ & $2.7 \mathrm{bc}$ & & $4.0 \mathrm{ab}$ & $3.8 \mathrm{a}$ & & $1.1 \mathrm{ab}$ & $2.1 \mathrm{~cd}$ \\
Taiwan Hybrid & $2.6 \mathrm{ab}$ & $2.6 \mathrm{~cd}$ & & $4.0 \mathrm{ab}$ & $2.1 \mathrm{~d}$ & & $1.3 \mathrm{ab}$ & $0.8 \mathrm{e}$ \\
Husainawiya & $2.7 \mathrm{ab}$ & $2.7 \mathrm{bc}$ & & $4.1 \mathrm{a}$ & $3.4 \mathrm{~b}$ & & $1.2 \mathrm{ab}$ & $2.2 \mathrm{~cd}$ \\
Hillawiya & $2.7 \mathrm{ab}$ & $2.8 \mathrm{abc}$ & & $4.1 \mathrm{a}$ & $3.3 \mathrm{~b}$ & & $1.3 \mathrm{ab}$ & $2.4 \mathrm{abcd}$ \\
Lahluba & $2.2 \mathrm{~b}$ & $2.2 \mathrm{~d}$ & & $4.2 \mathrm{a}$ & $2.8 \mathrm{~cd}$ & & $0.3 \mathrm{c}$ & $0.8 \mathrm{e}$ \\
Musoliya & $3.0 \mathrm{a}$ & $3.0 \mathrm{ab}$ & & $4.2 \mathrm{a}$ & $3.1 \mathrm{bc}$ & & $0.8 \mathrm{~b}$ & $1.8 \mathrm{~d}$ \\
Betraa & $2.8 \mathrm{a}$ & $3.0 \mathrm{ab}$ & & $4.3 \mathrm{a}$ & $3.3 \mathrm{~b}$ & & $1.4 \mathrm{ab}$ & $3.1 \mathrm{a}$ \\
\hline
\end{tabular}


M. incognita completes a full life cycle in approximately 20 days at $30^{\circ} \mathrm{C}$ and higher temperatures of $30-35^{\circ} \mathrm{C}$ may result in delayed adult phase and thus egg laying (Ploeg and Maris, 1999; Ploeg and Stapleton, 2001). The overall summer temperature in Iraq often exceeds $30^{\circ} \mathrm{C}$ and for more than five months from mid-April to late August. This may explain the overall low final nematode population and thus the reproduction factor of this nematode in this study. Both RKN species used in this study were affected by the high temperature, as plants were grown in plastic pots where soil had higher temperature than under field conditions (Thomason and Lear, 1961). Time may also be an important factor affecting nematode population density. In a comparative study, it was found that the number of $M$. incognita was lower than that of $M$. javanica or $M$. arenaria during the first 30 to 60 days of the study, but there were no differences in the final population after 90 days (Loubser and Meyer, 1987). M. javanica was more tolerant to higher temperature (up to $36.5^{\circ} \mathrm{C}$ ) even under soil conditions with rapid succession of humidity and drought periods (Trudgill et al., 2005). Thus, it is not surprising that $M$. javanica reproduced at much higher rate under optimum condition of $25 \pm 3^{\circ} \mathrm{C}$ resulting in $\mathrm{Rf}$ that ranged from 1.9 to 13 on okra grown under controlled growth room (Karajeh and Salameh, 2015). Similarly, $M$. incognita resulted in higher $\mathrm{Rf}$ that ranged from 1.09 to 8.2 under optimum temperature $\left(25 \pm 2^{\circ} \mathrm{C}\right)$ on okra in a pot experiment under field conditions (Mukhtar et al., 2014). Similar rates of reproduction were found in our study although the low reproduction factor of both nematode species due to high temperature conditions for the same period (60 days). Although some okra cultivars evaluated in this study were found to be resistant to one or both RKN species, they showed various degrees and types of resistance and tolerance as RKN species differed (Jacquet et al., 2005). Cultivars are susceptible to nematodes when the plant supports high levels of nematode reproduction (Canto-Saenz, 1985; Williamson, 1998). Thus, susceptibility can be measured by the pathogen reproductive factor or the final population in an infected host plant. Unlike susceptible cultivars, tolerant cultivars have less or no differences from un-inoculated plants in terms of growth or yield in the presence of nematodes (Cook and Starr, 2006). A tolerant cultivar can be either resistant or susceptible and vice versa. A combination of both resistance and tolerance can be measured and found in some economic and cash crops (Cook and Evans, 1987). Selecting okra cultivars resistant and tolerant to Meloidogyne spp. is an effective approach to maintain high yield, mitigate yield costs and manage the nematode population. Such cultivars may also be introduced to breeding programs to produce new cultivars resistant/tolerant to nematodes infection.

\footnotetext{
الملخص

كندوح، باسل، علاء حسن، أسماء عبد الرسول وبرنت سايبس. 2019. الكثف عن الحساسية والتحمل للإصابة بليدان تعقد الجذور Meloidogyne incognita وavanica و في أصناف البامية المزروعة في العرلق. مجلة وقاية النبات العربية، 37(3): 279-285. تمت غربلة عشرة أصناف من البامية لمقاومتها/قابليتها وتحملها للاصابة بنيماتودا تعقد الجذور وذلك بإلقاح شتلات بعمر 14 يوماً بـ 3000 بيضة/يافعة من

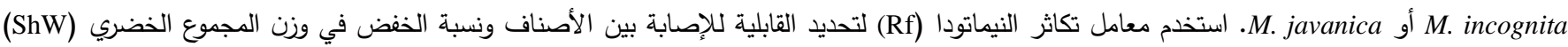

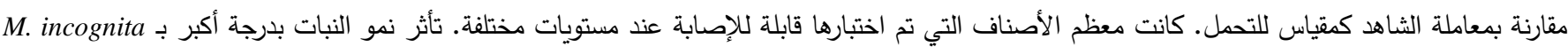

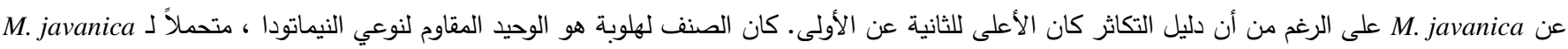

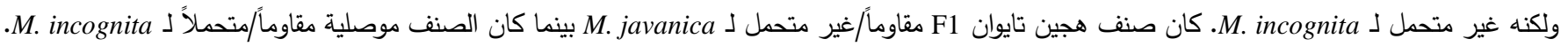
كان صنف بتراء أعلى الاصناف قابلية للإصابة بكلا النوعين، حيث كان متوسط التحمل لـ M. javanica وغير متحمل لـ M. incognita. كان صنف كلف كليمسون سباينس قابل للإصابة/متحمل لـ Mncognita، اما الأصناف الأخرى فكانت قابلة للإصابة غير متحملة. يمكن الاعتماد على نسبة الخفض بمؤشرات النمو (الوزن

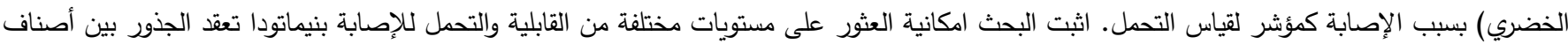

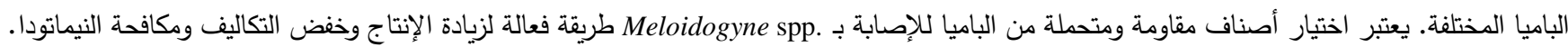

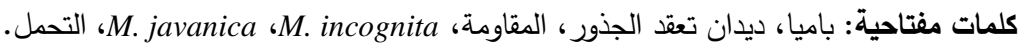

\section{References}

Al-Sabie, R.F. and S.N. Ami. 1990. Identification of races of root-knot nematodes Meloidogyne spp. in northern Iraq. Arab Journal of Plant Protection, 8: 83-87.

Alwaily, D.S., T.Y. Moder and A.Z.A. Alasadi. 2011. Integrated control of okra root knot disease caused by Meloidogyne javanica (Treub) chitwood. Journal of Basrah Research Sciences, 37: 31-43.
Barker, K.R. 1985. Nematode extraction and bioassays. Pages 19-35. In: An Advanced Treatise on Meloidogyne, Volume 2. Methodology. K.R. Barker, C.C. Carter and J.N. Sasser (eds.). North Carolina State University Graphics, Raleigh, North Carolina.

Brown, C.R., C.-P. Yang, H. Mojtahedi and G.S. Santo. 1996. RFLP analysis of resistance to Columbia rootknot nematode derived from Solanum bulbocastanum 
in a BC2 population. Theoretical and Applied Genetics, 92: 572-576.

https://doi.org/10.1007/BF00224560

Canto-Saenz, M. 1985. The nature of resistance to Meloidogyne incognita (Kofoid \& White) Chitwood, 1949. Pages 225-231. In: An Advanced Treatise on Meloidogyne. Volume I -Biology and Control. J.N. Sasser and C.C. Carter (eds.). North Carolina State University Graphics, Raleigh, North Carolina.

CSOI (Central Statistic Organization). 2016. Annual Statistical Group, Ministry of Planning, Iraq.

Cook, R. and K. Evans. 1987. Resistance and tolerance. Pages 179-231. In: Principles and Practice of Nematode Control in Crops. R.H. Brown and B.R. Kerry (eds.). Academic Press, New York.

Cook, R. and J.L. Starr. 2006. Resistant cultivars. Pages 370-391. In: Plant Nematology. R.N. Perry and M. Moens (eds.). CAB International, Wallingford, UK.

Darekar, K.S. and M.S. Ranade. 1990. Resistance of some okra, Abelmoschus esculentus, cultivars to rootknot nematode, Meloidogyne incognita. International Nematology Network Newsletter, 7: 6-7.

Das, S., D.A. DeMason, J.D. Ehlers, T.J. Close and P.A. Roberts. 2008. Histological characterization of rootknot nematode resistance in cowpea and its relation to reactive oxygen species modulation. Journal of Experimental Botany, 59: 1305-1313.

https://doi.org/10.1093/jxb/ern036

Eisenback, J.D. 1985. Diagnostic characters useful in the identification of the four most common species of root-knot nematodes (Meloidogyne spp.). Pages 95112. In: An advanced treatise on Meloidogyne, 1 Biology and control. J.N. Sasser and C.C. Carter (eds.). North Carolina State University, Raleigh, USA.

FAO (Food and Agriculture Organization). 2016. FAOSTAT Agriculture Data. FAO Statistical Databases. Available at: apps.fao.org

Garcia, G.M., H.T. Stalker, E. Shroeder and G. Kochert. 1996. Identification of RAPD, SCAR, and AFLP markers tightly linked to nematode resistance genes introgressed from Arachis hypogaea. Genome, 39: 836-845.

Haydock, P.P.J., S.R. Woods, I.G. Grove and M.C. Hare. 2006. Chemical control of nematodes. Pages 392-410. In: Plant Nematology. R.N. Perry and M. Moens (eds). CAB International, Wallingford, UK

Hussain, M.A., T. Mukhtar and M.Z. Kayani. 2014. Characterization of susceptibility and resistance responses to root-knot nematode (Meloidogyne incognita) infection in okra germplasm. Pakistan Journal of Agricultural Sciences, 51: 319-324.

Hussey, R.S. and K.R. Barker. 1973. A comparison of methods of collecting inocula of Meloidogyne spp., including a new technique. Plant Disease Reporter, 57: 1025-1028.

Ibrahim, I.K.A., M.A. Rezk and H.A.A. Khalil. 1982. Reaction of fifteen malvaceous plant cultivars to rooknot nematodes, Meloidogyne spp. Nematologia Mediterranea, 10: 135-139.
Jacquet, M., M. Bongiovanni, M. Martinez, P. Verschave, E. Wajnberg and P. CastagnoneSereno. 2005. Variation in resistance to the root-knot nematode Meloidogyne incognita in tomato genotypes bearing the Mi gene. Plant Pathology, 54: 93-99. https://doi.org/10.1111/j.1365-3059.2005.01143.x

Jain, R.K. and D.C. Gupta. 1996. Germplasm screening and control of root-knot nematode (Meloidogyne javanica) through seed treatment in okra. Indian Journal of Nematology, 26: 244-245.

Kandouh, B.H. 2018. Susceptibility and tolerance of okra cultivars to the Najaf populations of Root-knot nematodes Meloidogyne spp. and the use of natural nutrients to reduce infection. PhD Thesis, Faculty of Agriculture, University of Kufa, Iraq

Karajeh, M.R. and N.M. Salameh. 2015. Evaluation of Okra Landraces and Accessions Response to the Root-Knot Nematode, Meloidogyne javanica. Jordan Journal of Agricultural Sciences, 11: 735-745.

Kedarnath, N.G. Ravichandra, D.M. Preethi, B.M.R. Reddy, B.S. Pavithra and R.S. Pavithra. 2017. Screening of okra (Abelmoschus esculentus) cultivars for resistance against root knot nematode (Meloidogyne incognita) under field condition in Karnataka, India. International Journal of Current Microbiology and Applied Sciences, 6: 3420-3426. https://doi.org/10.20546/ijcmas.2017.611.402

Loubser, J.T. and A.J. Meyer. 1987. Population dynamics of the root-knot nematodes Meloidogyne incognita (Kofoid \& White) Chitwood and M. javanica (Treub) Chitwood on grapevines in two different regions of South Africa. South Africa Enology and Viticulture, 8: 36-40. https://doi.org/10.21548/8-2-2312

Mahajan, R. and B.R. Sharma. 1979. Resistance to rootknot nematode (Meloidogyne incognita) in okra (Abelmoschus esculentus Moench). Vegetables Science, 6: 137-138.

Martinello, G.E., N.R. Leal and J.C. Pimentel. 2001. Resistance of okra genotypes to Meloidogyne incognita race 2 and $M$. javanica. Horticulture Brasilia, 19: 115-117.

McDonald, B.A. and C. Linde. 2002. Pathogen population genetics, evolutionary potential, and durable resistance. Annual Review of Phytopathology, 40: 349-379.

https://doi.org/10.1146/annurev.phyto.40.120501.101 443

Mohanta, S. and K.C. Mohanty. 2012. Screening of okra germplasms/varieties for resistance against Meloidogyne incognita. Journal of Plant Protection and Environment, 9: 66-68.

Mukhtar, T., M.A. Hussain, M.Z. Kayani and M.N. Aslam. 2014. Evaluation of resistance to root-knot nematode (Meloidogyne incognita) in okra cultivars. Crop Protection, 56: 25-30. https://doi.org/10.1016/j.cropro.2013.10.019

Noe, J.P. 1985. Analysis and interpretation of data from nematological experiments, Pages 187-196. In: An advanced treatise on Meloidogyne. Vol. II: Methodology. K.R. Barker, C.C. Carter and J.N. 
Sasser (eds.). N.C. State University Graphics, Raleigh, USA.

Ploeg, A.T. and P.C. Maris. 1999. Effects of temperature on the duration of the life cycle of a Meloidogyne incognita population. Nematology, 1: 389-393. https://doi.org/10.1163/156854199508388

Ploeg, A.T. and J.J. Stapleton. 2001. Glasshouse studies on the effects of time, temperature and amendment of soil with broccoli plant residues on the infestation of melon plants by Meloidogyne incognita and $M$. javanica. Nematology, 3: 855-861. https://doi.org/10.1163/156854101753625353

Ramakrishnan, S., G. Rajendran and S. Vadivelu. 1993. Race identification of Meloidogyne incognita and evaluation of okra, Abelmoschus esculentus (L.) germplasm for resistance against $M$. incognita race 3 . Current Nematology, 4: 211-214.

Rekha, A.R. and D.N. Gowda. 2000. Screening of okra germplasm and varieties for resistance against Meloidogyne incognita. Indian Journal of Nematology, 30: 249.

Roberts, P.A. 2002. Concepts and consequences of resistance. Pages 23-41. In: Plant Resistance to Parasitic Nematodes. J.L. Starr, R. Cook and J. Bridge (eds.). CAB International, Wallingford, UK.

Roberts, P.A., W.S. Matthews, J.D. Ehlers and D. Helms. 2008. Genetic determinants of differential resistance to root-knot nematode reproduction and galling in lima bean. Crop Science, 48: 553-561. https://doi.org/10.2135/cropsci2007.07.0384

Sasser, J.N., C.C. Carter and K.M. Hartman. 1984. Standardization of host suitability studies and reporting of resistance to root-knot nematode. North Carolina State University, Department of Plant Pathology, Raleigh, NC, USA.

Sharma, W. and P.C. Trivedi. 1990. Screening of some okra cultivars for resistance against Meloidogyne incognita. International Nematology Network Newsletter, 7: 13-15.

Sheela, M.S., Jiji, R. Malu and S. Shaiju. 2006. Screening of okra varieties for resistance against Meloidogyne incognita. Indian Journal of Nematology, 36: 292293.

Sikora, R.A. and E. Fernandez. 2005. Nematode parasites of vegetables. Pages 319-392. In: Plant Parasitic Nematodes in Subtropical and Tropical Agriculture. M. Luc, R.A. Sikora and J. Bridge (eds.). CABI Publishing, London, UK
Singh, R.K., R.R. Singh and R.C. Pandey. 1993. Screening of okra, Abelmoschus esculentus varieties/cultivars against root-knot nematode, Meloidogyne incognita. Current Nematology, 4: 229232.

Stephan, Z.A. 1988. Plant parasitic nematodes on cereals and legumes in Iraq. Pages 155-159. In: Nematodes parasitic to cereals and legumes in temperate semiarid regions. M.C. Saxena, R.A. Sikora and J.P. Srivastava (eds.). ICARDA, Aleppo, Syria.

Stephan, Z.A., I.K. Hassoon and B.G. Antoon. 1998. Use of biocontrol agents and nematicides in the control of Meloidogyne javanica root-knot nematode on tomato and eggplant. Pakistan Journal of Nematology, 16: 151-155.

Taylor, A.L. and J.N. Sasser. 1982. Relationship of Climate and Soil Characteristics to Geographical Distribution of Meloidogyne spp. in Agricultural Soils. A Cooperative Publication of Dept. of Plant Pathology, North Carolina State University and US/AID, 65.

Taylor, D.P. and C. Netscher. 1974. An improved technique for preparing perineal patterns of Meloidogyne spp. Nemalologica, 20: 268-269.

Thies JA, S.B. Merrill and E.L. Corley. 2002. Red food coloring stain: new, safer procedures for staining nematodes in roots and egg masses on root surfaces. Journal of Nematology, 34: 179-181.

Thies, J.A. and R.L. Fery. 1994. Evaluation of okra cultivars for resistance to Meloidogyne incognita. Journal of Nematology, 26: 567-568.

Thomason, I.J. and B. Lear. 1961. Rate of reproduction of Meloidogyne spp. as influenced by soil temperature. Phytopathology, 51: 520-524.

Trudgill, D.L., A. Honek, D. Li and N.M. Van Straalen. 2005. Thermal time - concepts and utility. Annals of Applied Biology, 146: 1-14. https://doi.org/10.1111/j.1744-7348.2005.04088.x

Williamson, V.M. 1998. Root-knot nematode resistance genes in tomato and their potential for future use. Annual Review of Phytopathology, 36: 277-293. https://doi.org/10.1146/annurev.phyto.36.1.277

Williamson, V.M. and P.A. Roberts. 2009. Mechanisms and genetics of resistance. Pages 301-325. In: Rootknot Nematodes. R.N. Perry, M. Moens and J.L. Starr (eds.). CAB International, Wallingford, UK.

تاريخ الاستلام: 2018/8/24؛ تاريخ الموافقة على النشر: 2019/7/4 